The International Journal of Engineering and Science (IJES)

|| Volume || 6 || Issue || 5 || Pages || PP 16-21 || 2017 ||

ISSN (e): $2319-1813$ ISSN (p): $2319-1805$

THE IJES

\title{
Energy Conscious Design Elements in Office Buildings in Hot- Dry Climatic Region of Nigeria
}

\author{
Hussaini Haruna ${ }^{1}$, Usman Bukar Wakawa ${ }^{2}$, Abdul Anakobe Isa ${ }^{3}$, Aminu Umar ${ }^{4}$. \\ Department of Architecture Abubakar Tafawa Balewa University Bauchi
}

\begin{abstract}
-
The indoor environments are becoming increasingly important for human comfort and from health point of view. It is estimated that high percentage of the global energy demand is coming from buildings. Majority of the buildings' occupants in Mubi are thermally uncomfortable in their offices and homes especially in the summer, because the climate is characterized by clear skies, high solar radiation, low air humidity and typically large diurnal temperature range. This study aimed to access the adequacy level of energy conscious design elements on the senate building of Adamawa State University, Mubi. Observation checklist was used; the checklist contains the research variables which are the identified elements of energy conscious design. The result shows that the energy conscious design elements on the cased building are inadequate. Considering the nature of the climate in the study area-characterized by hot-dry for most period of the year. In order to enhance the comfort of the occupant, such buildings should be designed to have adequate energy conscious design element.
\end{abstract}

Keywords: Energy Conscious, Climate, Thermal Comfort, Passive Design

Date of Submission: 14 April 2017

$\longrightarrow$ Date of Accepted: 30 April 2017

\section{INTRODUCTION}

Buildings consume large amount of energy and resources and they causes a number of environmental problems as a result of their construction, operation and maintenance (Vyas et al, 2014). The amount of energy consumed by building depends on the type of building, usage, and total occupancy (Shende et al, 2012).

Majority of the buildings (offices) occupants in Mubi are thermally uncomfortable in their offices and homes, because the climate is characterized by clear skies, high solar radiation, low air humidity and typically large diurnal temperature range (Ibrahim et al, 2014). The climate is generally hot and dry for most period of the year (Nimet, 2015). The mean temperature recorded at most meteorological stations is about $37 \mathrm{c}$. The highest temperature of about $40^{\circ} \mathrm{c}$ is normally experienced in the month of April while the minimum temperature of about $27^{\circ} \mathrm{c}$ is usually recorded in December (Nimet, 2015).

Energy conscious design approach helps designers/architects in reducing building cost economically and conveniently, while improving comfort for the building's residents (Morris, 2013). Passive Architecture involves the use of eco-friendly and less energy intensive materials for construction of building, incorporating passive solar principles in building design and operation including day lighting features, integration of renewable energy, methods to conserve water, waste water recycling techniques, rainfall harvesting and use of appliances in buildings that are energy efficient. (Gulati and Paul, 2013). Passive cooling can be adopted as a viable alternative to conventional cooling system because conventional means of creating thermal comfort are energy intensive and it maximizes the efficiency of the building envelope by minimizing heat gain from the external environment and facilitating heat loss through various natural sources of cooling such as air movement, cooling breeze, evaporation and earth coupling. Good envelope design responds to climate and site conditions and further optimizes thermal performance (Gulati \& Paul, 2013).

Energy efficient building mostly incorporates solar architecture with modern technologies such as BIPV (building integrated photovoltaic), use of solar fridges, solar water heating, and energy efficient building materials to ensure that maximum comfort is attained with reduced energy cost without harm to the environment/climate (Nwofe, 2014). Currently, most buildings in Nigeria lay more emphasis on the aesthetic values with little or no consideration for energy efficiency (Nwofe, 2014).

\section{Principles of Energy Conscious Design}

An energy efficient building is designed to deliver maximum comfort to occupants by making the most of free natural heating, cooling, lighting and utilizing efficient design principles and building materials to reduce the need for appliances. According to Gulati \& Paul (2013) for a building to be energy efficient it needs to have all the correct elements of design, which are listed as follows; 


\section{Building Envelope}

The building envelope is the interface between the interior of the building and the outdoor environment, including the walls, roof, and foundation (Energy Land, 2016). By acting as a thermal barrier, the building envelope plays an important role in regulating interior temperatures and helps determine the amount of energy required to maintain thermal comfort (Energy Land, 2016). In cold climates, the building envelope can reduce the amount of energy required for heating; while in hot climates, the building envelope can reduce the amount of energy required for cooling (PewClimate, 2011). A substantial part of "weatherization" includes improvements to the building envelope, and government weatherization programs often cite energy and energy bill savings as a primary rationale for these initiatives (PewClimate, 2011). The building envelope therefore should be designed to reduce the amount of radiation into the building in order to enhance the comfort of occupant during summers.

\section{Vegetation/Landscape}

Shade from trees intercept sunlight before it warms a building, the urban forest cools the air by evapotranspiration (Apollomapping, 2013). Trees also decrease the wind speed under their canopy and shield buildings from cold winter breezes. Urban shade trees offer significant benefits by both reducing building air conditioning and lowering air temperature, and thus improving urban air quality by reducing smog (Singh \& Yadav, 2016).

An energy conscious building in the study area therefore should be surrounded by trees from appropriate positions to benefit improving urban quality and enhancing indoor air quality and comfort.

\section{Site Selection}

Analysis of a development site and its characteristics is a key element in the design process for maximizing use of the sun's energy, heat and light (Akadiri et al, 2012). Site analysis involves assessing a range of environmental factors that can affect the development of a site. However, site planning is an interactive process, beginning with defining the overall goal for energy use and cost in the proposed building determining the most effective solar concepts to achieve this goal. In addition, this information can determine how to plan the site for the building. Site-specific conditions such as land form, vegetation, open spaces, water bodies etc. play an important role in design of any building. Analysis can be done for these conditions to enable one to choose a site and make suitable design plans (Gulati \& Paul, 2013). Thus, site selection for an energy conscious building should be based on those features mentioned above, as the site have access to all those features or elements.

\section{Orientation of Buildings}

Building orientation refers to the way a building is situated on a site and the positioning of windows, rooflines, and other features (Pai \& Siddhartha, 2015). A building oriented for solar design takes advantage of passive and active solar strategies. Passive solar strategies use energy from the sun to heat and illuminate buildings. Building orientation and building materials also facilitate temperature moderation and natural day lighting. Active solar systems use solar collectors and additional electricity to power pumps or fans to distribute the sun's energy (NJ GreenBuilding, 2011).

Appropriate orientation can help to eliminate the undesirable effects of severe weather to a great extent. For example, in cold weather conditions, a building must be oriented to receive maximum solar radiation into the living areas for warmth on one hand, while keeping out the prevailing cold winds on the other (Gulati and Paul, 2013).

\section{Area to Volume Ratio (S/V Ratio)}

The surface area to volume ratio (S/V) is an important factor for the performance of a building (Ghodsi, M., et al, 2014). The greater the surface area, the greater will be the potential heat gain or loss through it. Consequently, a small S/V ratio implies minimum heat gain and heat loss. In order to minimize unwanted losses and gains through the fabric of a building, it's desirable to design a compact shape (Schenkel, 2012).

\section{Building Configuration}

Shape and surroundings of any building plays a very import role in governing the energy consumption in any building, which may cause heat gain when cooling is required and heat loss when heat gain is required (Maracineanu \& Bica, 2015). For any given enclosed building volume, there are numerous ways in which actual dimensions of height, length and breadth can vary resulting in different total surface areas. Thus two buildings, both having the same volume and built of the same materials, may have quiet different surface areas and hence different rate of heat loss and heat gain (CLEAR, 2012).

Configuring the geometry of the building appropriate to the climate and usage can control the magnitude of the heat flow. Wind when obstructed by a building creates pressure differences, creating positive pressure on the windward side and negative pressure on the leeward side. Consequently, a new airflow pattern gets developed 
around the building (Gulati \& Paul, 2013). Thus, wind pattern across any building can get modified by shaping it appropriately. Structures can be designed to conserve energy in both winter and summer. Shading devices such as chajjas block the solar radiation incident on the exposed surfaces of a building, consequently reducing heat gain. Buffer spaces such as courtyards, atria, balconies and verandahs provide shading and catch wind (Gulati \& Paul, 2013).

Therefore, for a building to be energy conscious in Mubi, all these factors relating to building configuration should be properly put into consideration.

\section{Building Components}

The nature of a building envelope determines the amount of radiation and wind that will enter the building. It consists of Roof, Walls, Ground-based floor, fenestrations, external color and texture (Gulati \& Paul, 2013). The heat flow through these elements is characterized by their resistance, thermal capacity, absorption, transmission and emission. Windows act as the means of achieving desired solar heat gains, natural light and ventilation. They can also be the major route of internal heat loss and excessive heat gain resulting in overheating. Walls offer opportunities for solar heat gain and act as a source for internal heat loss through exhaust fans and vents, gaps around window, door frames, joints between walls, ceilings and floors etc. (Gulati \& Paul, 2013).

In view of this, building components should be design to perform the function of allowing and disallowing the passage of heat to the building, during winter and summer respectively.

Table 1.0 Criteria of Shading

\begin{tabular}{|l|l|}
\hline Climate Zones & Requirements \\
\hline Hot and dry & Complete year round shading \\
\hline Warm and humid & Complete year round shading, but design should be made such that ventilation is not affected \\
\hline Temperate & Complete year round shading but only during major sunshine hours \\
\hline Cold and cloudy & No shading \\
\hline Cold and sunny & Shading during summer months only \\
\hline Composite & Shading during summer months only \\
\hline
\end{tabular}

Source: Singh \& Yadav, 2016

\section{METHODOLOGY}

The case-study research approach was adopted. There are number of instrument used for collecting the data, these instruments includes; Observation (with observation checklist) and Interview. The observation checklist was designed to enable the researcher to assess and rate the identified research variables successfully.

\section{The Study Variables}

The variables are the energy conscious design elements of a building identified by Gulati and Paul, (2013).

- $\quad$ Building Envelop

- Landscape/Vegetation

- Building Orientation

- Building Configuration

- $\quad$ Building Component

Case Study: Senate Building, Adamawa State University, Mubi.

ADSU Senate Building (Office) Approach

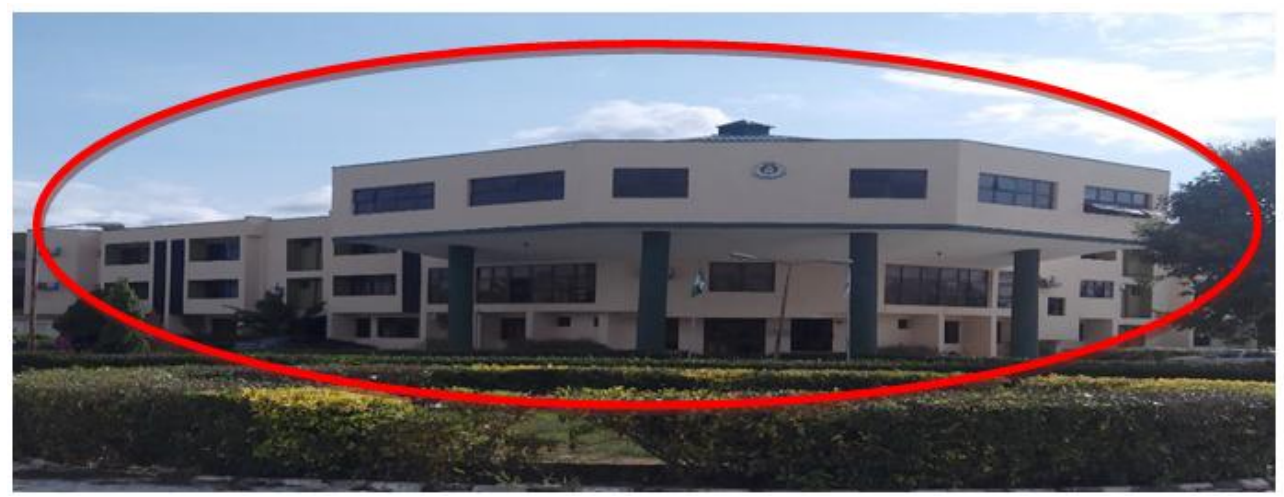

Exposed Council Chamber at Southern Side without adequate vegetations/trees 


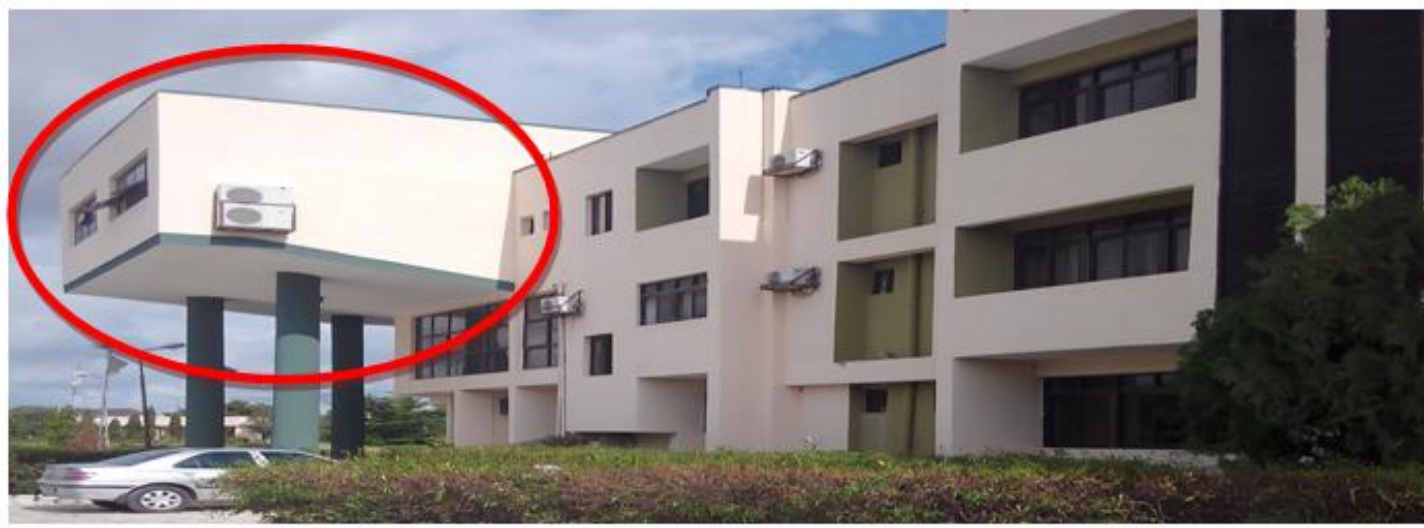

Exposed Pentagonal shaped Senate Chamber

Ground Floor Plan showing the shape of the Building (Bad Orientation)

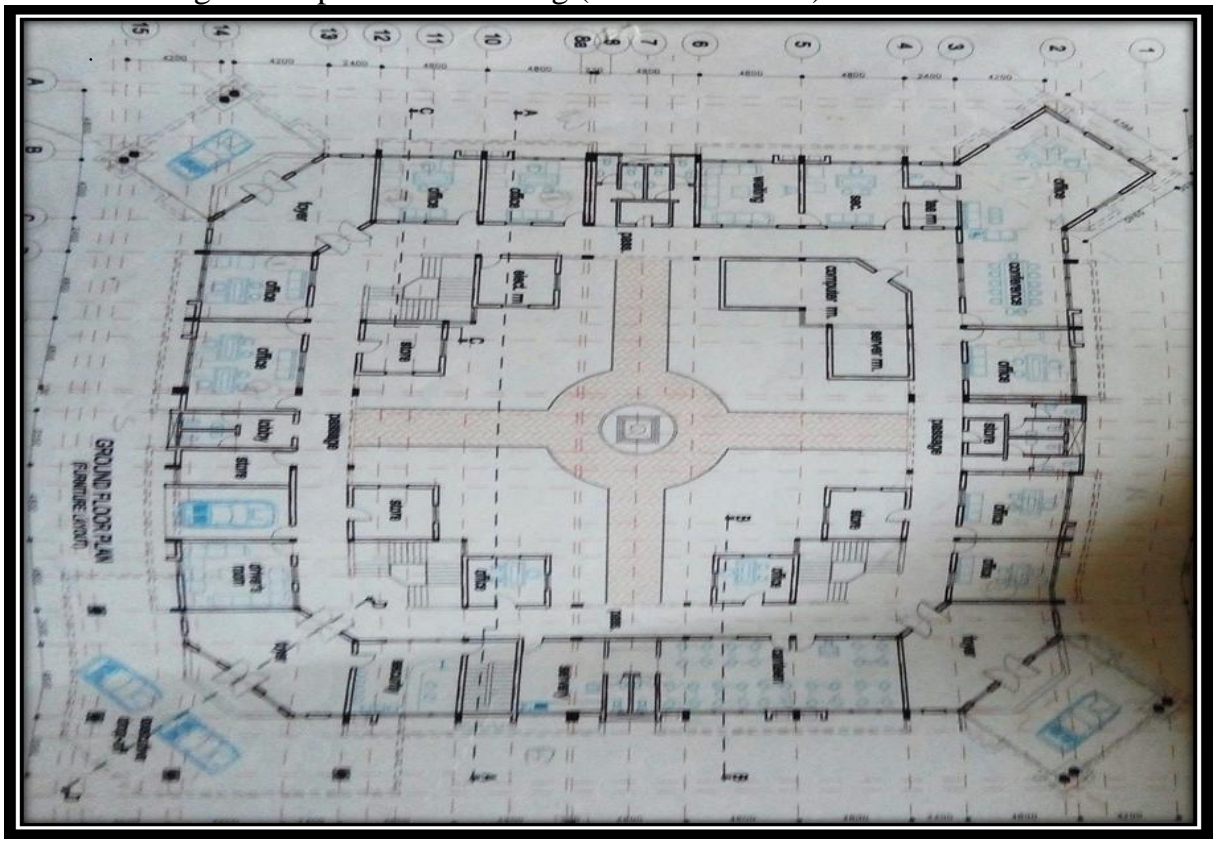

Table 1: Checklist for the Assessment of Energy Conscious Design Elements on Existing ADSU Senate Building.

(Rating Key: 1=Poor, 2=Not Adequate, 3=Fairly Adequate, 4=Adequate, 5=Very Adequate)

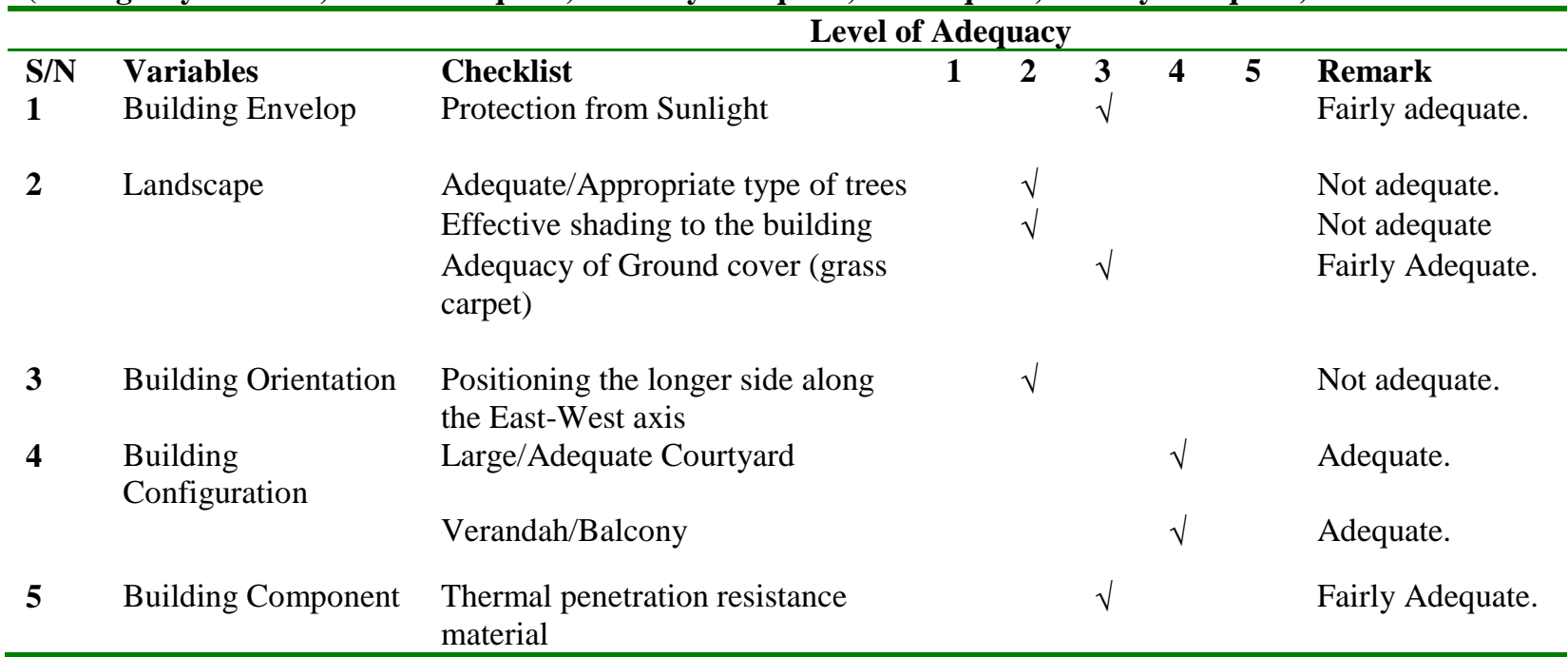

Source: Researcher 2016 
Table 2. Summary of Results

\begin{tabular}{lccc}
\hline $\mathbf{S} / \mathbf{N}$ & Variables & Average Score & Remark \\
\hline $\mathbf{1}$ & Building Envelope & 3 & Fairly Adequate \\
$\mathbf{2}$ & Landscape & 2 & Not Adequate \\
$\mathbf{3}$ & Building Orientation & 2 & Not Adequate \\
$\mathbf{4}$ & Building Configuration & 4 & Adequate \\
$\mathbf{5}$ & Building Component & 3 & Fairly Adequate \\
\hline
\end{tabular}

Source: Researcher, 2016

The result from the above shows that out the five variables (Energy Conscious Design Elements), only one, the Building Configuration is adequate, the landscape and Building Orientation are not adequate, while Building Envelop and Building Component are just fairly adequate. Hence, the energy conscious design elements of the ADSU senate building are therefore not adequate.

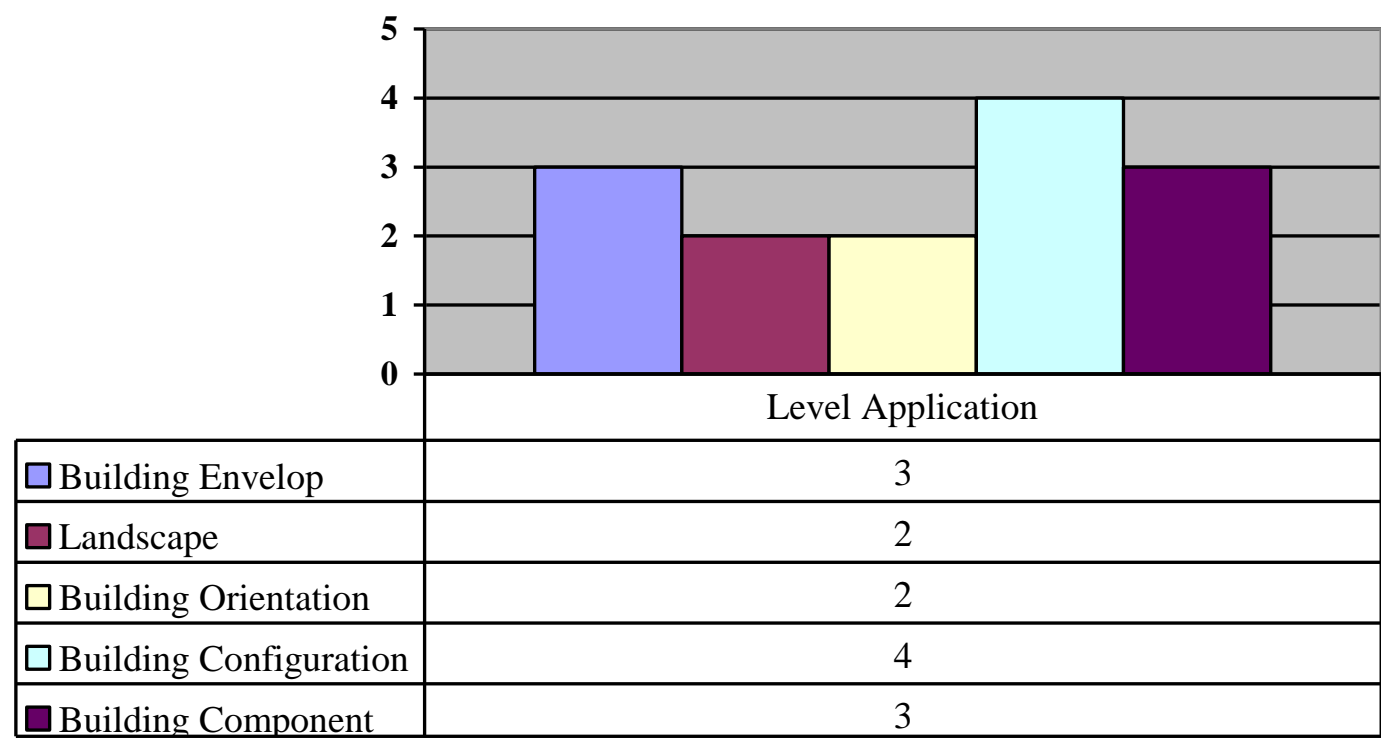

Fig.1. Chart showing the level of Adequacy plotted against variables, for ADSU Office Complex.

\section{DISCUSSION}

Based on the results available, the Building Envelope is just fairly adequate, that is not properly minimizing the amount of radiation into the building. The soft landscape (vegetation) around the building is also not adequate for Energy Conscious Design as the soft landscape should cover the highest percentage of the area around the building. The senate buildings attempted to have a good orientation but the shape/form of the building (squared) sabotages the effort, hence, it does not have adequate orientation as there are equal openings from all the four corners of the building. Only the Building Configuration is at adequate level; this is because of the provision of large courtyard with some vegetation, the internal verandah, and the recesses/balconies protect and put most part of the building under shed. The Building Component is fairly adequate; this is because of the nature of the fenestrations, external walls, external colour and texture.

\section{CONCLUSION}

Energy conscious design has been a very important design approach. It is an aspect of sustainable architecture as it has been used in achieving comfort in building without adopting mechanical equipment. It is called 'energy conscious' because it not only useful in the summers where buildings are more aggressive in terms heat to the user. However, in winter where the user of building need solar heating in order to feel comfortable in the building. Hence, it is an important approach in achieving thermal comfort in buildings.

Energy conscious design can only be successful by incorporating both passive cooling and passive heating strategies. Passive Architecture involves the use of eco-friendly and less energy intensive materials for construction of building. Passive cooling can be adopted as a viable alternative to conventional cooling system because conventional means of creating thermal comfort are energy intensive and hence harmful to ecological system. Passive design maximizes the efficiency of the building envelope by minimizing heat gain from the 
external environment. It is also important to know that energy conscious design involve the use of renewable energy systems (solar photovoltaic systems) to meet part of building load requirements.

The application of energy conscious design in office building is equally very important just like in residential buildings. Studies have shown that the potential for energy savings for an energy efficient building is as high as $40-50 \%$ if addressed right at the design stage.

\section{REFERENCES}

[1]. Akadiri, P.O. et al (2012). Design of Sustainable Building: A Conceptual Framework for Implementing Sustainability in the Building Sector. Buildings 2012,2, 126-152; doi: 10.3390/buildings 2020126

[2]. Apollomapping (2013). Outside the Box- Shade Trees. Retrieved on $27^{\text {th }}$ February, 2017 from; https://apollomapping.com/blog/outside-box-shade-trees

[3]. CLEAR, (2012). Comfortable Low Energy Architecture: Building Configuration. Retrieved $29^{\text {th }}$ January, 2017 from; http://www.new-learn.info/packages/clear/thermal/buildings/configuration/index.html

[4]. EMSD Energy Land, (2016). Building: Building Envelope. Retrieved on 28 ${ }^{\text {th }}$ February, 2017 from; http://www.energyland.emsd.gov.hk/en/building/energy_use/envelope.html

[5]. Ghodsi, M., et al. (2014). A Survey of the Impact of Surface on Volume Ratio (SVR) of Residential Buildings on Thermal Behaviour. Advances in Environmental Biology. ISSN-1995-0756 EISSN-1998-1066. Pages: 625-632

[6]. Gulati, M.,Paul, A. (2013) Principles of Energy Conscious Design: Association of Computer Electronics and Electrical Engineers, Proc. of Int. Conf. on Emerging Trends in Engineering and Technology.

[7]. Ibrahim et al, (2014) Improvement of Thermal Comfort In Residential Buildings, International Journal of Science and technology, Volume 3, Issue 3, March 2014

[8]. Maracinenu, C., Bica, S.M. (2015). Architectural and Energy Performance Analysis: A Case Study of a New Building in Timisoars. Mediamira Science Publishers. Vol. 56, 1-2, 2015

[9]. Nayak, J.K., Prajapati, J.A (2006). Hand Book on Energy Conscious Buildings. Indian Institute of Technology, Bombay, India. Retrieved on $30^{\text {th }}$ January, 2017 from; http://www.mnre.gov.in/solar-energy/startpage.pdf

[10]. Nimet (2015) Nigerian Metrological Agency, Weather Forecast. Retrieved 13 ${ }^{\text {th }}$ December 2015, from; www.nimet.gov.ng

[11]. NJ Green Building Manual, (2011). New Commercial Update: Building Orientation. Retrieved on 30 ${ }^{\text {th }}$ January, 2017 from; http://greenmanual.rutgers.edu/newcommercial/strategies/buildingorientation.pdf

[12]. Pai, M.Y., Siddhartha (2015). Effect of Building Orientation and Window Glazing on the Energy Consumption of HVAC System of an Office Building in for Different Climatic Zones. International Journal of Engineering Research and Technology (IJERT) ISSN: 2278-0181 Vol. 4 Issue 09, September-2015

[13]. PewClimate, (2011). Climate Tech Book: Building Envelope. Retrieved on 31st January, 2017 from https://www.c2es.org/docUploads/BuildingEnvelope.pdf

[14]. Schenkel, S. (2012). Grun Eco Design: Sustainable Architecture. Retrieved on $29^{\text {th }}$ January 2017 from; http://gruenecodesign.com.au/surface-area-to-volume-ratio-building-shape/ 